\title{
Class Conflict, Political Crisis and the Breakdown of Democratic Practices in Costa Rica: Reassessing the Origins of the I948 Civil War*
}

FABRICE EDOUARD LEHOUCQ

\section{Introduction}

The 1948 Costa Rican civil war stands as the most significant breakdown of emerging democratic practices in what many believe is a country with a democratic destiny. ${ }^{1}$ No other political conflict has so polarised the country and cost so many lives. Nor has any other civil war so influenced the way analysts view and understand the development of democratic institutions in Costa Rica. Why political actors in Costa Rica settled their disputes on the battlefield, however, is a question that has yet to generate a satisfactory response.

The immediate precedent of the civil war was the annulment of the presidential election by the Constitutional Congress on I March I 948. The election, allegedly won by the opposition candidate Otilio Ulate Blanco and his Party of National Unification (PUN), occurred in an environment of intense party competition, not infrequently characterised by the use of violence and fraud. These results were questioned by members of the governing political party (the National Republican Party [PRN]) loyal to the government's favourite and former president of the Republic between I 940 and i944, Dr Rafael Angel Calderón Guardia.

* The initial (and major) drafts of this article were written while I was a Visiting Professor, School of History and Research Associate, Centre for Historical Investigations, University of Costa Rica. I wish to acknowledge the support of the Social Science Research Council and the American Council of Learned Societies for an International Doctoral Research Fellowship that funded the research upon which this paper is based.

1 For an evaluation of alternative explanations of the democratisation of Costa Rican politics, see my 'Explicando los orígenes de los regímenes democráticos: Costa Rica en perspectiva teórica', Anuario de Estudios Centroamericanos (San José, Costa Rica), Vol. I6, Fasc. I (1990).

Fabrice Lehoucq is a Graduate Instructor of Political Science at Duke University. 
In the weeks that followed, attempts to negotiate a pact between the opposition and government proved fruitless. Attempts to effect such political compromises became pointless once the forces led by José Figueres Ferrer made clear to other political actors their intention to organise a junta to rule Costa Rica for what eventually became a period of eighteen months. ${ }^{2}$ During its brief rule, the junta convened a National Constituent Assembly that refashioned Costa Rican political institutions by, among other things, creating a politically autonomous electoral court system and enfranchising all Costa Ricans over the age of $20 .^{3}$

Images of these events diverge among Costa Ricans. ${ }^{4}$ Many see 1948 as the culmination of the Calderonistas' attempts to install a corrupt dictatorship in Costa Rica. ${ }^{5}$ The PRN is also lambasted for commencing an alliance with the Popular Vanguard Party, PVP (the Costa Rican communist party), during Calderón Guardia's presidency, an alliance solidified by his successor, Teodoro Picado. In these accounts, Figueres is portrayed as the saviour of Costa Rica's democratic heritage. Indeed, the most recent attempts to discuss Costa Rican democracy credit Figueres with not only vanquishing the 'Caldero-comunista' regime, but with making the key decisions leading to the consolidation of the politically stable democratic regime present in Costa Rica since $1949 .{ }^{6}$ It was in this year, after all, that the Figueres junta relinquished power to President-

2 This period remains unstudied, except for John W. Gardner, 'The Costa Rican Junta of I 948-49', unpubl. PhD dissertation, St John's University, I97 I.

3 Studies of the National Constituent Assembly are: Oscar Aguilar Bulgarelli, La constitución de 1949: antecedentes y proyecciones (San José, 1973) and Mario Alberto Jiménez, Historia constitucional de Costa Rica (San José, 1979), pp. i 54-69. A detailed account of each of the Assembly's sessions can be found in Ruben Hernández Poveda, Desde la barra: como se discutió y emitió la Constitución Politica de 1949 (San José, 1953). Hernández Poveda covered Assembly debates as a reporter for the daily evening paper, La prensa libre (San José, Costa Rica).

4 For an overview of the political debate about the meaning of the 1940s, see Mariana Campos Vargas, 'La coyuntura, 1940-1948: el ascenso de nuevas fuerzas sociales y los cambios en las funciones del estado' in Jaime Murillo Viquez (ed.), Historia de Costa Rica en el siglo XX (San José, 1989). Also, see her 'La coyuntura 1940-48, entre el testimonio y la academia : un análisis historiográfico', unpubl. Master's Thesis, MA Programme in Central American History, University of Costa Rica, 1989.

5 The most succinct anti-Calderonista account of the 1940 s is Alberto F. Cañas, Los ochos años (San José, 1982; originally published in 1955). Also, see José Figueres Ferrer, Palabras Gastadas (San José, 1979; originally published in Mexico in 1942) and his recently published El espiritu del 48 (San José, 1987).

6 The ideological dominance of Figuerista images of 1948 is particularly acute among North American scholars. This is discussed in Lowell Gudmundson's useful review essay, 'Costa Rica and the 1948 Revolution: Rethinking the Social Democratic Paradigm', Latin American Research Review, vol. 19, no. I (1984). A recent attempt to interpret the events of the 1940 s in this way is John A. Booth, 'Costa Rica: The Roots of Democratic Stability', in Larry Diamond and Juan Linz (eds.), Democracy in Developing Countries: Latin America (Boulder, 1989). 
elect Ulate Blanco, the first individual to exercise the powers of the presidency under the new constitution.

Few other voices echo as loudly as those of the Figueristas. Though several prominent individuals of the old regime have left memoirs or written about diverse aspects of these years, their accounts either have not been made readily available or not received the attention they merit as alternative interpretations of the events surrounding the 1948 civil war. ${ }^{7}$

Common to the most prevalent images of the 1948 civil war is the belief that the conflict between a social reformist (but, many would add, a corrupt) government and an allegedly conservative opposition closely aligned with Costa Rica's coffee oligarchy could be settled only through the force of arms. Jorge Mario Salazar Mora neatly summarises this widely accepted belief when he writes that:

the 1948 election could not resolve peacefully the dispute between the two political groupings of that epoch, because the degree of social tension between class fractions and classes exceeded the limits of peaceful coexistence. Consequently a trial of strength was required to restructure the state apparatus and re-accommodate social forces. ${ }^{8}$

In this essay I will probe the veracity of this belief.

For many, raising this issue is pointless because it leads to counterfactual reasoning of dubious utility. Yet I suggest that not pursuing this line of inquiry implies the more troublesome assumption that the civil war was inevitable. To the extent that the volition of individuals is discussed, the proponents of the strong inevitabilist thesis see individuals and other political agents as actors caught in a play that, by definition, possesses preestablished roles. Though perhaps none of the chroniclers of the r 9405 quite so openly adopts the strong inevitabilist thesis favoured by Salazar Mora, they all share a number of its essential corollaries, as I shall show in this article.

What is pernicious about the inevitabilist thesis, I argue, is that it leads to the under-reporting of evidence and/or the refusal to explore issues

7 The most comprehensive account of the 1940 s by a Calderonista is José Albertazzi Avendaño, La tragedia de Costa Rica (México, D. F., I95 I). The limited diffusion of antiFiguerista accounts is nicely illustrated by the fact that Albertazzi Avendaño's memoirs cannot be found in the holdings of the National Library, even though he served as its director during the 1930 . Other useful sources include Teodoro Picado, El pacto de la embajada de México (Managua, 1948) and the writings of Manuel Mora Valverde, many of which have been published in his Discursos, 1934-1979 (San José, 1980).

8 See his ' $E$ l sistema político-electoral costarricense del período $19^{1} 4^{-1} 1948^{\text {', in Historia }}$ de Costa Rica en el siglo XX, p. 5 I. Also, see Claudio A. Vargas A., 'La guerra civil de 1948: la sustitución del modelo liberal', in Carmen Lila Gómez et al. (eds.), Las instituciones Costarricenses del Siglo XX (San José, 1988). I have sought to translate all passages contained in the text of this article into English from Spanish in the most literal fashion that the proper use of English permits. 
that do not fit with whatever version of this thesis the analyst is either covertly or overtly propounding. Assuming that the 1948 civil war was inevitable helps to obscure the role played by different political actors; sustains distorted images of the nature and significance of the 1948 civil war; and cripples the study of the origins of democratic institutions in Costa Rica. That both those who focus on the behaviour of politicians and those who seek to uncover the 'real' economic roots of the 1948 civil war are inevitabilists suggests that the study of this conflict may benefit from critical reflection.

The principal objective of this essay is to suggest that compelling reasons exist for re-interpreting the origins and significance of the 1948 civil war. It begins by discussing the most important, largely political accounts of the 1948 civil war. It then examines the arguments made by what are here labelled class and economic interpretations of the 1940s. It then argues that extant ways of understanding the origins of the 1948 civil war are undermined by the existence of questionable empirical claims and dubious theoretical conclusions. The conclusion sketches an alternative way of conceptualising political conflict that unravels the puzzles left unresolved by the principal analysts of the 1948 civil war.

\section{Political perspectives}

The two most important political chronicles of the events leading to the I 948 civil war are the books by Oscar Aguilar Bulgarelli and John Patrick Bell. ${ }^{9}$ Although Miguel Acuña, Eugenio Rodríguez Vega and Jacobo Schifter (in one of his books not examined in this article) have written on the politics of this period, I do not classify their volumes along with those of Aguilar Bulgarelli and Bell, because the former three authors pursue different objectives. ${ }^{10}$ Acuña is more interested in questioning certain beliefs about the events of 1948 , largely through the use of interviews with key individuals and a reading of select documents. Rodríguez Vega's book is essentially a well-written set of personal recollections about the 1940s,

9 Aguilar Bulgarelli's book is entitled Costa Rica y sus hechos politicos de 1948: problemática de una década (San José, 1969). Bell's volume is called Crisis in Costa Rica: the 1948 Revolution (Austin, 1971). This book was translated and published in Costa Rica by EDUCA in 1976 . All page citations refer to the English-language version of Bell's book.

10 See Miguel Acuña, El 48 (San José, 1975); Eugenio Rodríguez Vega, De Calderón a Figueres (San José, 1981); and Jacobo Schifter Sikora, Las alianzas conflictivas: las relaciones de Estados Unidos y Costa Rica desde la segunda guerra mundial a la guerra fria (San José, 1986). Schifter's book was originally presented as a doctoral dissertation in the department of history, Columbia University, in 1983 under the title of 'The Origins of the Cold War in Central America: A Study of Diplomatic Relations Between Costa Rica and the United States (1940-48)'. A preliminary version of this book was published as Costa Rica, 1948: análisis de los documentos confidenciales del departamento de estado (San José, 1982). 
buttressed by some minor primary source research. Schifter delineates the course taken by US-Costa Rican relations during the i 940 ond thereby furnishes a wealth of previously little-known information on the events of I948. Aguilar Bulgarelli and Bell's efforts merit special consideration because they are the only attempts to examine comprehensively the politics of the 1948 civil war.

In broad outline, Aguilar Bulgarelli and Bell offer similar accounts of the relations between the government and opposition during the r 940 . The differences between their books are minor and stem from the fact that Bell, as a Tulane University graduate student conducting research for his $\mathrm{PhD}$ dissertation, provides a more analytical account of the $\mathrm{I} 940 \mathrm{os}$ than Aguilar Bulgarelli. The narratives of these two authors attempt to uncover the multiplicity of factors that influenced the behaviour of key political figures and political parties during this decade. Through a description of such events and processes, Aguilar Bulgarelli and Bell seek to explain why the conflict between government and opposition led to the outbreak of armed hostilities in 1948 .

Both Aguilar Bulgarelli and Bell trace the origins of the deep rift between the opposition and the governments of Calderón Guardia and Picado to the early years of the Calderón presidency. In a series of events that remain unclear and understudied, Aguilar Bulgarelli and Bell suggest that Calderón Guardia's declaration of war on Germany, Italy and Japan during the last weeks of I94 I alienated key members of Costa Rica's dominant class, many of whom were purportedly German and Italian immigrants or their descendants and/or sympathisers of the Axis powers. These individuals, along with the former president between 1936 and I940, León Cortés Castro, and his followers began to organise a new political party, the Democratic Party (PD) in opposition to Calderón Guardia's government. Allegedly most of Costa Rica's wealthy, led by Cortés Castro, became entrenched opponents of the government once Calderón Guardia began a series of reforms that gave birth to the Costa Rican Social Security System (194I), the country's first Labour Code (1943) and the amendments to the constitution, known as the Social Guarantees (1943), among other programmes. The withdrawal of support by his former reluctant backer, Cortés Castro, and the reputed hostility of key sectors of Costa Rica's dominant class are seen as the reasons why Calderón Guardia formed an alliance with the Communist party, led by its congressman, Manuel Mora Valverde. This alliance also received the tacit support of Monseñor Víctor Manuel Sanabria, Costa Rica's Roman Catholic Archbishop. ${ }^{11}$

11 The famed alliance between the Communist party and Calderón Guardia's government is discussed by Gerardo Contreras and José Manuel Cerdas, Los años cuarenta: historia 
Both accounts then describe the increasing polarisation between opposition and government in Costa Rica. The opposition's charges of fiscal corruption and nepotism against what they began to refer to as 'Caldero-comunismo' soon attracted the support of Otilio Ulate Blanco, publisher of a leading daily, the Diario de Costa Rica, and a former congressman. ${ }^{12}$ The ranks of the opposition also were joined by the group of young intellectuals of the Centre for the Study of National Problems (CEPN), who in 1945 combined forces with the small political party, Democratic Action (AD), to form the Social Democratic Party (PSD). ${ }^{13}$ Upon returning in 1944 from the exile imposed on him by Calderón Guardia in I 942, José Figueres began to participate in the affairs of both parties, when not attempting to organise an armed insurrection against Calderonismo. ${ }^{14}$

By 1945, violence and other forms of protest became widespread once elements within the opposition began to believe that the government would never permit official candidates to lose elections. In 1942, the first occasion in which the opposition attempted to participate in electoral politics, its efforts were stymied by officially sponsored or permitted electoral fraud (a resource frequently employed by Costa Rican governments to influence electoral results). The use of such fraud was repeated in the 1944 presidential and legislative elections that were marred by irregularities that, in the opposition's view, were of sufficient extent to suggest that fraud had prevented Cortés Castro from rightfully becoming Costa Rica's next president. Unfortunately, neither author attempts to organise systematically the many and varied reports of fraud existing in

de una politica de alianzas (San José, 1988). For additional discussions of Sanabria's role in the promulgation of these and related reforms, see Santiago Arrieta, El pensamiento socio-politico de Monseñor Sanabria (San José, 1977), Ricardo Blanco Segura, Monseñor Sanabria (San José, 1971) and Gustavo Adolfo Soto Valverde, La iglesia costarricense y la cuestión social: antecedentes, análisis y proyecciones de la reforma social Costarricense de 1940-43 (San José, 1985). Soto Valverde's book is particularly useful because it challenges the received opinion that Calderón Guardia needed to befriend the communists in order to avoid being overthrown by groups of angry capitalists. See especially pp. 1 89-347. This issue will be discussed in the next section of this article.

12 Despite his obvious importance in Costa Rican politics, Ulate Blanco has only received the attention of one biographer. See José Luis Torres, Otilio Ulate: supartido y sus luchas (San José, 1986).

13 See Jorge Enrique Romero Pérez, Acción Demócrata: los orígenes del Partido Liberación Nacional (de León Cortés a José Figueres) (San José, 1983) and La social democracia en Costa Rica (San José, 1982).

14 Biographies of José Figueres include: Charles D. Ameringer, Don Pepe: A Political Biography of José Figueres of Costa Rica (Albuquerque, 1978) and Arturo Castro Esquivel, José Figueres Ferrer: el hombre y su obra (San José, 1955). 
Costa Rican newspapers, or to examine other primary source material, to ascertain the veracity of opposition claims so that, at the very least, a more complete account of the nature, magnitude and distribution of electoral fraud could be established.

For these authors, the opposition's lack of faith in the government's willingness to hold fair elections became a key issue during the buelga de brazos caidos of late July I 947 . This strike succeeded in paralysing a portion of the nation's commerce, and only came to an end when President Picado signed a public agreement emphasising his commitment to holding nonfraudulent elections in 1948. Bell, in particular, also discusses the opposition's well-organised publicity campaign aimed at discrediting the government by repeating charges of fiscal and electoral corruption and by playing on the anti-communism of Costa Rican society and the US Embassy (ever more receptive to such efforts with the onset of the cold war). ${ }^{15}$ Finally, Aguilar Bulgarelli and Bell spend some time outlining government attempts to reorganise the electoral registry and to revamp electoral practices as required by the recently enacted 1946 Electoral Code, despite the increasingly apparent lack of time to do so.

Aguilar Bulgarelli and Bell devote many pages to describing the most salient events leading to the start of the civil war, once preliminary electoral results revealed that the opposition candidate, Ulate Blanco ( $54,93 \mathrm{I}$ votes), had defeated the government's favourite, Calderón Guardia ( 44,438 votes). They show how efforts by the National Electoral Tribunal (TNE) to tally the vote, and to issue a provisional verdict on the elections by 25 February, were hampered by the partial destruction of already deficient and incomplete electoral material in a mysterious fire. Both authors also point out that when Calderonistas, believing that large numbers of their voters were prevented from casting ballots, presented the TNE with a petition requesting that these elections be nullified, their claims were ridiculed by the opposition and met with indifference by the presiding members of the TNE. In the eyes of both Aguilar Bulgarelli and Bell, these events only confirmed the belief of each side in the untrustworthiness of the other, thus polarising the Costa Rican party system.

Consequently neither Aguilar Bulgarelli nor Bell expresses surprise that on I March (the constitutionally designated date requiring Congress to issue the final verdict on the presidential race in an election year) the Calderonista-dominated Congress nullified the election. Despite efforts by Monseñor Sanabria and others to mediate a solution between the government and opposition, the civil war is said to have begun on 12

15 See Schifter, Las alianzas conflictivas, for the most detailed discussion available of this issue. 
March when news reached San José that Figueres' makeshift army had exchanged gunfire with government troops. Both books also provide accounts of how Figueres had organised an army to lead such an insurrection, outline the course taken by the war and, finally, describe how key members of Costa Rica's diplomatic corps helped negotiate a ceasefire ending the war on ig April. Both Aguilar Bulgarelli and Bell end their volumes by discussing Figueres' triumphant march into San José, Picado's transference of power to the third presidential designate, Santos León Herrera, and, on 8 May, Figueres' consolidation of political power as leader of the de facto Junta Fundadora de la Segunda Repuiblica.

Despite their unstated premise that the 1948 civil war stemmed from a multiplicity of causes, neither author spends much time discussing, for example, the effects of the war-induced increase in the daily cost of living or the economic consequences of the social reforms. Neither Aguilar Bulgarelli nor Bell discusses, in any detail, the fiscal and foreign exchange crisis clearly in evidence by the end of Calderón Guardia's presidency. Yet both authors do assume that Calderón Guardia and Picado's reformist policies did alienate key sectors of Costa Rica's dominant class. They simply do not attempt to discover how these phenomena affected different social groups and whether these groups entered the electoral arena or otherwise sought to influence the nature of state policy.

\section{Class and economic perspectives}

It is the desire to discern links between economic developments and overt political conflict that inspired Jacobo Schifter's La fase oculta de la guerra civil, and also Lucha social y guerra civil en Costa Rica, 1940-1948 by Manuel Rojas Bolaños. Indeed, both Rojas Bolaños and Schifter essentially argue that less than favourable economic conditions and/or contradictory class forces inevitably led to the outbreak of armed conflict in 1948. In the course of developing this theme these two authors furnish data not previously well known, which they interpret by means of theoretical speculation.

Schifter's principal empirical contribution to the study of class alignments during the r 940 s is an ecological analysis of electoral returns during the 1950s and 1960s, which was originally produced by the North American political scientist, Robert Trudeau. ${ }^{16}$ Schifter's primary goal is

16 See chapter four of La fasa oculta de la guerra civil (San José, 1979). For Trudeau's analysis, see his 'Costa Rican Voting: Its Socioeconomic Correlates', unpubl. PhD diss., Department of Political Science, University of North Carolina, Chapel Hill, 197 I. As Schifter himself points out, this data should be analysed with a great deal of care. It should not be forgotten that this analysis hinges on electoral results from the decades following the civil war to interpret class alignments during the 1940s. Furthermore, as 
to contend that it was the Calderonista PRN along with its successors, and not either the PSD or its progeny, the National Liberation Party (PLN), that received the support of the urban working class and popular sectors as well as that of the workers on the banana estates owned by the United Fruit Company. Regrettably, Schifter does not speculate on the social bases of the opposition to Calderonismo.

He also makes what I think is a cogent argument, in chapter II, that the closing of the historically very important German market for Costa Rican coffee exports during World War II did not adversely affect either the economy or the interests of coffee growers. As Schifter points out, it was only between 1939 and I940 that the value of coffee exports declined. While total agricultural exports decreased between 1937 and I94I, the value of coffee exports increased after i940, because the US replaced Germany as the principal consumer of Costa Rican coffee. Schifter also contends that it remains unclear how the dominant class reacted to Calderón Guardia's jailing, or to the expulsion of members of Costa Rica's German community to US internment camps.

In his Lucha social y guerra civil en Costa Rica, Rojas Bolaños contends that the promulgation of social reforms between i94 I and I 943 drove a wedge between Calderón Guardia's (and later Picado's) government and the Costa Rican oligarchy. ${ }^{17}$ Alongside alleged capitalist dissatisfaction with the Calderón Guardia government, Rojas Bolaños argues that it also began to feel the effects of former president Cortés Castro's increasingly popular campaign for re-election in 1944 . He points out, for example, that the cost of living essentially doubled between i94 I and i944, most severely affecting the poorest social sectors. ${ }^{18}$ On the basis of this and related evidence, Rojas Bolaños concludes that 'the peasantry was more inclined to follow León Cortés, whom it remembered as the strong man who had piloted an ordered public administration'. The peasantry, because of inflation and the war-induced scarcity of basic consumer goods,

ecological analysis does not require the use of individual-level data, the correlations produced by Trudeau only measure the nature of the relationship between the overall social characteristics of, and the aggregate number of votes received by each party in, targeted cantons. The precise nature of class alignments within each canton remains unknown.

17 Rojas Bolaños, Lucha social y guerracivil en Costa Rica, 1940-1948 (San José, 1979), p. I 2. Also, see p. 45 for a slightly more extensive affirmation of the core idea of Rojas Bolaños' study.

18 The cost of living index rose from 109.1 3 in July 194 I to 189.29 points by December $1944(1936=100)$. Rojas Bolaños took his data, in Lucha social y guerra civil en Costa Rica, $1940-1948$, p. 8 I, from Rodrigo Facio, La moneda y la banca central en Costa Rica (México, D. F., I 947), p. I 8 I. Note: the edition of Facio's book cited by Rojas Bolaños is identical, except for its pagination, to the version I subsequently footnote. 
viewed the Calderón Guardia government with distaste, especially since 'administrative disorder and governmental corruption were so evident, and the benefits of the social reforms were not reaching the masses, above all the impoverished peasantry'. ${ }^{19}$ Unfortunately, this provocative interpretation is not complemented with an analysis of how urban workers, artisans and others were affected by the increase in the cost of living, or whether and how they mobilised to promote their interests.

The shortcomings of Rojas Bolaños' analysis of the political behaviour of the lower classes point to the difficulties associated with the view that class conflict caused the 1948 civil war. Contending that class struggle explains the outbreak of armed hostilities in 1948 requires the analyst to show why and how disputes over the distribution of material resources generated the principal political cleavages of Costa Rican society.

That class struggle was the motor of Costa Rican political history during the I 940 s is confirmed according to Rojas Bolaños, by the alleged existence of a rift between Calderón Guardia's government and the Costa Rican oligarchy. According to his view of the social world, states typically protect the interests of the dominant class, thus preserving the capitalist mode of production. ${ }^{20}$ That state officials and capitalists disagree, however, might suggest the limitations of such a functionalist theory of the state, rather than establishing the centrality of class conflict in Costa Rica in the I940s. It is confused thinking to assume that the consequences - in this case, public policies beneficial for the capitalist system - of any set of institutions such as the state can straightforwardly explain its existence. Doing so requires the use of functionalist instead of causal analysis and either denies, or cannot coherently account for, the role played by intentional subjects in human affairs. ${ }^{21}$

A class-centred interpretation of the I940s would also have to show that the interests of Costa Rican classes and class fractions were affected in divergent and adverse ways by economic changes and/or state policy. Finally, the class analyst would need to explain how and why these classes

19 Rojas Bolaños, Lucha social y guerra civil en Costa Rica, 1940-1948. The first quotation appears on the last paragraph of p. 91, the second near the bottom of p. 89 .

20 See ibid. pp. 32-3 and p. 39.

21 See his 'Marxism, Functionalism and Game Theory: The Case for Methodological Individualism', Theory and Society, vol. I I, no. 4 (July 1982) and his Making Sense of Marx (New York and London, 1986). It remains unclear whether Marxist theories can comprehend state behaviour. Theda Skocpol concludes that three important types of neo-Marxist theories of the state are fundamentally flawed because they cannot adequately comprehend the behaviour of the state in the United States during what Rojas Bolaños would label a 'período de crisis'. See her 'Political Response to Capitalist Crisis: Neo-Marxist Theories of the State and the Case of the New Deal', Politics and Society, vol. 10, no. 2 (1980). Also, see Axel Van den Berg, Immanent Utopia: From Marxism on the State to the State of Marxism (Princeton, 1988). 
and class fractions became organised as collective actors when (and if) their interests were threatened.

Available evidence indicates (as Rojas Bolaños, to his credit, admits) that the interests of the dominant class during Calderón Guardia's presidency were both threatened and safeguarded. ${ }^{22}$

The creation of the Social Security Institute and certain provisions in the Labour Code requiring employers to make compensation when dismissing employees undoubtedly angered industrialists, merchants, and agriculturists. How did capitalists actually respond to Calderón Guardia's reformist policies? Relying upon the oft-quoted opinions of Mora Valverde, the longtime leader of the Costa Rican Communist Party, Rojas Bolaños contends that, by 1942, Calderón Guardia's social reforms had alienated many of the country's capitalists. Manuel Mora Valverde testifies that sometime during the first months of 1942 he was invited by Mariano Cortés (a PRN deputy since 1936) to attend a meeting in the home of Jorge Hine (the General Manager of the Bank of Costa Rica), where a group of capitalists were allegedly organising a coup to overthrow Calderón Guardia's government. ${ }^{23}$ The argument is that, confronted by such opposition, Calderón Guardia decided to form an alliance with the Costa Rican Communist Party as a way of increasing his social base of support. ${ }^{24}$ Capitalist dissatisfaction with Calderón Guardia's drift to the Left also is revealed, according to Rojas Bolaños, by the fact that key members of Costa Rica's dominant class, like Jorge Hine, Frederico Rohrmoser, Marco A. González L., Carlos Gutiérrez and Roberto Salazar M. had endorsed Cortés' presidential candidacy by $1943 .{ }^{25}$

Many other capitalists, however, did not feel that the alleged danger posed by Calderón Guardia's reforms warranted their backing Cortés Castro's bid for the presidency. Indeed, one member of the Executive Committee of the PD, Congressman Luís Calvo Gómez, argued that Cortés Castro lost the 1944 election in part because he never attracted the

22 Rojas Bolaños, Lucha social y guerra civil en Costa Rica, 1940-48, p. 8 I.

23 Rojas Bolaños, ibid. p. 81. The source of this claim is the interview, 'Fundación del Partido Vanguardia Popular', Entrevista no. I hecha por Oscar Aguilar Bulgarelli al señor Manuel Mora Valverde, in Oscar Aguilar Bulgarelli, Costa Rica y los hechos politicos de 1948 , anexo I, pp. 489-91. There is a discussion of this famous incident on pp. 55-7 of Aguilar Bulgarelli's book. No one is sure exactly when this meeting took place. Rojas Bolaños, Lucha social y guerra civil en Costa Rica, 1940-48, p. 97, n. I, also suggests it took place during the first part of i 942. But Soto Valverde, La Iglesia Costarricense $y$ la cuestion social, pp. 289-97, provides convincing evidence that Mora Valverde's views are factually incorrect and, by implication, that the dominant class did not unite against Calderón Guardia's government because of its alleged dislike of these social reforms. This and the next paragraph rely heavily upon Soto Valverde's arguments.

24 Rojas Bolaños, Lucha social y guerra civil en Costa Rica, 1940-48, p. $8 \mathrm{I}$.

25 Rojas Bolaños, ibid., p. 92 refers to an article in Diario de Costa Rica (26 March 1943) that makes this information public knowledge. 
support of the Costa Rican dominant class. ${ }^{26}$ On at least one occasion (in August 1943) other members of Costa Rica's dominant class, including José Joaquín Alfaro, Tomás Malavassi, Mariano Cortés, Fausto Coto Monge, and Walter Dittel, signed a public letter in support of the recently enacted Labour Code. ${ }^{27}$ That Congressman Mariano Cortés signed this declaration after he reputedly was plotting a coup against Calderón Guardia's administration suggests that proponents of the received wisdom have not bothered to construct an empirically consistent interpretation of Costa Rican history.

Capitalist approval of or indifference towards the government no doubt stemmed from the fact that dominant class interests were affected in divergent ways by state policy. Coffee growers and exporters must have been pleased when Calderón Guardia's government announced in 1940 that it would guarantee a minimum price for coffee exports, as well as eliminating taxes on such exports. ${ }^{28}$ Not surprisingly, then, during the I 940 s conflicts in the coffee sector continued their post-1930 decline in importance and number. ${ }^{29}$ The government also must have made additional friends among Costa Rica's wealthy when it passed a law in I 940 aimed at protecting new industrialists from foreign competition. ${ }^{30}$

After 1944 Picado's government shied away from submitting a monetary law to Congress once Manuel Francisco Jiménez Ortiz, a key spokesman of Costa Rican liberalism, had launched a campaign against the proposed bill. ${ }^{31}$ Picado did, however, provoke the ire of most entrepreneurial associations at the end of 1946, when his government gained legislative approval for new income and property taxes. ${ }^{32}$

26 See his 'Don León Cortés murió lamentándose de la indiferencia de los capitalistas', Diario de Costa Rica (San José), no. 8,325 (22 Dec. 1946), pp. I, 5.

27 The letter mentioned in the previous sentence is dated 5 August 1943 and is printed in Soto Valverde, La iglesia Costarricense y la cuestión social, pp. 337-8.

28 See Rodrigo Facio, La moneda y la banca central en Costa Rica (San José, 1973), pp. is 2-6 for an analysis of these measures.

29 Víctor Hugo Acuña Ortega, 'Patrones del conflicto social en la economía cafetalera costarricense (1900-1948)', Revista de Ciencias Sociales (San José, Costa Rica), no. 3 I (March 1986).

30 See 'Ley No. 36 (2 I December 1940)', Colección de leyes y decretos (San José, 1940), pp. 739-42. This law was subsequently reformed. See 'Ley No. 641 (14 Aug. 1946)', Colección de leyes y decretos (San José, 1946).

31 This occurred during the autumn of 1945 . See Facio, La moneda y la banca central en Costa Rica, pp. $285-95$ for a brief description of the government's abandonment of its proposed monetary laws.

32 An account of this campaign from one of its proponents can be found in Manuel $F$. Jiménez, Intervenciones Públicas (San José, 195 I), pp. I3-43. The government's position on its financial policies is defended by the Minister of Finance, Alvaro Bonilla Lara, La aplicación de las leyes de ordenamiento fiscal (San José, 1947) and by President Picado in his Impuesto sobre la renta (San José, 1947). These three originally published their views in the pages of Diario de Costa Rica and La tribuna during the first two months of 1947. 
Merchants also began to criticise government economic policy when the Picado administration could not easily solve the severe foreign exchange crisis produced by the resumption of imports from industrialised countries at the end of World War II. ${ }^{33}$

However, the collective behaviour of capitalists (or any other class), cannot be inferred solely from an analysis of their class interests. ${ }^{34}$ It is still necessary to show how and why individual capitalists should have orchestrated a campaign to seek remedy from economic policies harmful to the capitalist class as a whole. Delineating how capitalists, in pursuit of their common class interests, dealt with the possibility of reprisals and the uncertainty regarding the behaviour of their colleagues, allies and opponents is thus an essential component of political analysis.

An examination of the political consequences of the Picado administration's income and property taxes reveals that capitalists and middleclass professionals reacted in divergent ways to a policy that slightly reduced their individual as well as common incomes. ${ }^{35}$ In the days after these taxes became law, staunch and long-term opponents of Calderonismo did persuade their middle-class colleagues in an assembly of professionals not only to abstain from paying the new taxes, but also to participate in a general strike. ${ }^{36}$

The 300 of the estimated I, 500 members of Costa Rica's entrepreneurial associations who attended a hastily organised assembly could only agree to declare their willingness to consider not paying the recently enacted income and property taxes. Capitalists in attendance refused to heed the advice of hardline middle-class professionals, who were also attempting to get a motion approved calling for a tax boycott and a general strike. Fearing government sanctions, Alvaro Zúñiga of the Costa Rican

33 A useful overview of this problem is Rodrigo Facio, 'El problema de las divisas', Obras bistóricas, vol. I (San José, 1975) [this study was originally published in San José in 1950].

34 Perhaps the first systematic attempt to explain the divergence between individual and common interests is Mancur Olsen, The Logic of Collective Action (Cambridge, 1965). For a pathbreaking explanation of capitalist behaviour in the light of these theories, see John R. Bowman, Capitalist Collective Action: Conflict and Cooperation in the Coal Industry (New York and London, 1989). Also, see Claus Offe and Helmut Wisenthal, 'Two Logics of Collective Action', reprinted as chapter four in Claus Offe, Disorganised Capitalism (Cambridge, 1985) for a discussion of the different types of collective action problems confronting capitalists and workers.

35 Both taxes were progressive in nature. They are reprinted and discussed in 'Dictamen de la Comisión de Hacienda del Congreso Constitutional', La gaceta: diario oficial, no. 281 (1० Dec. 1946), pp. 2,209-12.

36 'Ir a la huelga de brazos caídos se propusó anoche en la reunión de profesionales', Diario de Costa Rica, no. 8, 23 (20 Dec. 1948), pp. I, 8. The hardliners included Lic. Ramón Arroyo Blanco, Dr Luís Dobles Segreda, Dr Antonio Peña Chaverria, Dr Carlos Luís Valverde Vega and congressman Fernando Volio Sancho. 
Chamber of Commerce spoke for many when he argued that no illegal measures should be adopted by the poorly attended assembly. An indication that Zúñiga's opinions were widely held was the inability of assembly organisers to obtain the signatures of those present for a petition containing the motion passed. The decision in favour of moderation was confirmed by the Chamber of Commerce in its first general assembly of I 947, when it publicly declared that it would not adopt illegal or violent tactics in its efforts to have the new tax laws repealed. ${ }^{37}$ Their alleged dislike of Picado's presidential administration did not deter bankers from floating a loan to his government at the end of 1947 nor prevent them from acting as intermediaries in search of a peaceful compromise between the government and opposition in the months preceding the start of the civil war. ${ }^{38}$

It is clear that the interests of the dominant class were adversely affected as well as favoured by state policy during the i $940 s$. That an unknown number of capitalists often criticised the government is also undeniable. What remains unproven and indeed improbable is the claim that capitalists organised a collective movement dedicated to overthrowing a regime allegedly inimical to their interests.

Rojas Bolaños, however, remains unwilling to allow such facts to modify his view that the civil war was the product of class conflict. He settles for asserting that the class interests of all social groups found expression in different political parties during the i940s. For example, Rojas Bolaños claims that Cortés Castro and the PD were supported by 'the large agroexport bourgeoisie - coffee growers and bankers - as well as a large portion of the large import merchants'. Similarly, he suggests that 'medium-sized businessmen and professionals of some renown, of progressive tendencies, began to surround Otilio Ulate'. I assume that Rojas Bolaños believes this group was joined by the sectors supporting Cortés Castro once he died in the aftermath of the 1946 congressional elections. According to Rojas Bolaños, the CEPN and the AD, as well as its successor, the PSD, represented 'a serious alternative to official reformism, started by circles of intellectuals of petty bourgeois extraction, fundamentally, and medium-sized businessmen in coffee or other, different productive branches of this industry'. Finally, in what is surely Rojas

37 'No pago de impuestos acordó la asamblea de anoche', Diario de Costa Rica, no. 8,324 (2 I Dec. 1946), pp. I, 8; 'En numerosa asamblea convocada por las Cámaras representivas se acordó la abstención total del pago de impuestos', La prensa libre, no. I 3,995 (2 I Dec. I 946), pp. I, 6; 'Movimiento de resistencia para el pago de impuestos', La tribuna, no. 7,855 (2 I Dec. 1946), pp. I, 3; 'Solemnemente declara la Cámara de Comercio que no usará métodos ilegales o violentos contra las nuevas leyes tributarias', La tribuna, no. 7,867 (10 Jan. 1947), pp. I, 2.

38 'Resolución No. 16 (19 Dec. 1947)', Cartera de Hacienda y Comercio, Colección de leyes $y$ decretos (San José, 1947), pp. 341-2. 
Bolaños' most innovative interpretation, he concludes that Calderonismo 'formed a fraction of the national bourgeoisie, differentiated from the rest of this social class not by the productive branch where it invested its capital ... but by its modernising ideas' (italics in the original). ${ }^{\mathbf{3 9}}$

Aside from artful theoretical embellishments, Rojas Bolaños fails to supply any evidence that supposed class interests found their political expression in the way he outlines. Unfortunately, this is a practice mimicked by other Marxist-influenced historians and sociologists who analyse the i 940 . In Los años cuarenta, Gerardo Contreras and José Manuel Cerdas also conceptualise political parties and other political vehicles as projections of often poorly defined class interests. ${ }^{40}$ In their respective and widely read books, Jorge Rovira Mas and Jorge Mario Salazar Mora also contend that the behaviour of political actors was determined by class interests. ${ }^{41}$ While not nearly as explicit (nor as extreme) as Rojas Bolaños, Schifter too adopts such a perspective in La fase oculta de la guerra civil.

While it may be true that political parties did attract supporters from these social classes, it is not clear whether party conflicts represented the clash of clearly identifiable class interests. For example, the CEPN, the AD and the PSD might be petty bourgeois in origins, but this is such a heterogeneous class that elements of it could easily be motivated by nonclass interests and/or by diverse economic interests or grievances to support a variety of different political parties. The clumsiness of Rojas Bolaños' theoretical premises is best revealed by the inconsistency of asserting that all political parties represented groups possessing contradictory positions in the mode of production, except Calderonismo. Unfortunately, the anomaly of locating Calderonismo's interests in the realm of ideas is never satisfactorily addressed by Rojas Bolaños.

Ironically, Aguilar Bulgarelli and Bell also adopt a variant of this portrait of social and political dynamics. Without succumbing to the worst aspects of a class reductionist perspective, both Aguilar Bulgarelli

39 With the exception of the last quotation, all other citations can be found in Rojas Bolaños, Lucha social y guerra civil en Costa Rica, $1940-48$, p. 103. The quotation about Calderonismo as a class fraction is on p. 48.

40 Los años cuarenta, pp. 8-9, 72-82, 86, 97, 105 , and 120 for numerous examples of class reductionism. It is interesting to note that Contreras and Cerdas, ibid. pp. 8-9, once refer to the work of Mario Ramírez Boza to substantiate their conceptualisation of Costa Rican class structure. Yet neither they nor Ramírez Boza supply evidence linking classes and class fractions to political organisations. Indeed, Ramírez Boza does not seem to want to attempt to pursue this objective. That, at least, is my reading of Ramírez Boza's 'El desarrollo de las clases sociales y la industria en Costa Rica (1880-1930)', unpubl. Master's Thesis, Master's Programme in Central American Sociology, University of Costa Rica, 1983.

41 See Jorge Rovira Mas, Estado y politica económica en Costa Rica, 1948-1970, tercera edición (San José, 1988), esp. pp. 39-1 18 and the 'anexo teórico', where the class reductionism of his approach is discussed in painful detail; and Jorge Mario Salazar Mora, Politica y reforma en Costa Rica, 1914-1958 (San José, 1981), esp. pp. 67-134. 
and Bell also visualise the 1948 civil war as the inevitable clash of competing social sectors. Aguilar Bulgarelli, for example, tends to see the I 940 s as the appearance of reformist presidents compelled to form an alliance with the Communist party because of the opposition of the oligarchy. From his perspective, the alliance between oligarchical interests and the CEPN and the PSD remains a mystery, as the latter two groups represented the aspirations of a frustrated social class whose class interests were not well served by such an alliance. ${ }^{42}$ Bell also employs a similar set of concepts, though he clearly identifies this frustrated social group as that of Costa Rica's emergent middle sectors. ${ }^{43} \mathrm{He}$ also remains perplexed as to why this nation's middle class refused to form a coalition with Calderonismo and chose instead to work with Costa Rica's most conservative economic sectors. Other analysts do not even seem concerned by this puzzle. Susanne Jonas Bodenheimer, Claudia Quirós V. and Jorge Rovira Mas do not even furnish the appropriate sociological evidence when they assert that the outcome of the 1948 civil war represented the triumph of the middle class, or what they prefer to see as Costa Rica's version of the conquering industrial bourgeoisie. ${ }^{\mathbf{4 4}}$

Until we question the widely held belief that the 1948 civil war was caused by class conflict, troublesome evidence on the subject will continue to cause unnecessary perplexity. Analysts will ignore the fact that dominant class interests were both helped and harmed by state policy

42 See: 'No nos explicamos como un grupo de jóvenes intelectuales, de la calidad de un Rodrigo Facio, quienes accedieron a unirse con un solo bloque, con el sector conservador de la política nacional, que veía en todo lo que tenía color de reforma social, un aspecto negativo para la buena marcha del país, para sus instituciones y para sus intereses particulares pues estaban convencidos de que debían seguirse pié a pié, los postulados del liberalismo económico del siglo XIX.' See his Costa Rica y sus bechos politicos de 1948, p. 246. On pp. 297-8, Aguilar Bulgarelli explicitly refers to the frustration of the middle class. He does so by referring to the book by Juan Bosch entitled Una interpretación de la historia costarricense (San José, 1980; originally published in 1963$)$.

43 This is made very clear in chapter one of Bell's book. Indeed, the North American fascination with José Figueres stems precisely from the supposed middle-class character of Figueres' political movement. It should be remembered that when Bell travelled to Costa Rica during the late ig6os to conduct the research for his book, North American policy-makers and academics expected the Latin American middle classes to become non-communist, democratic reformers of their poverty-stricken societies. A book that nicely summarises this position is John J. Johnson, Political Change in Latin America: The Emergence of the Middle Sectors (Palo Alto, 1958). It is also never very clear to Bell why this group disliked Calderonismo, nor why Costa Rica's middle-class reformer achieved and maintained power in an undemocratic fashion.

44 Susanne Jonas Bodenheimer, La ideología social demócrata en Costa Rica (San José, 1984); Claudia Quirós V., Los tribunales de probidad y de sanciones inmediatas (San José, 1989), pp. 23-34 [these tribunales were hastily arranged courts that tried members of Calderón Guardia and Picado's governments during Figueres' rule]; Jorge Rovira Mas, Estado y politica económica en Costa Rica, 1948-1970. 
during the i 940 . The behaviour of individuals and classes will continue to be inferred inadequately from their often poorly understood class interests. Within this framework political alliances during the i 940 s will always remain an unresolved paradox. Most importantly, it will not be possible to explain why the ballot box failed to select a presidential candidate in 1948 acceptable to government and opposition, why numerous attempts to negotiate a peaceful transference of political power ultimately collapsed, and why those who triumphed on the battlefield gained control of the state.

\section{An alternative view of the 1948 civil war}

Attempts to understand the origins of the 1948 civil war might begin by visualising this conflict as a breakdown of electoral institutions. The inability of political actors to accept the results of the 1948 presidential election was a sufficient - though perhaps not also a necessary - condition for the outbreak of armed hostilities in the weeks after this election was held.

Framed in this way, it is important to ask why electoral mechanisms were questioned by political actors in the period preceding these elections and thoroughly discredited by the members of the PRN and the PVP once they were held. ${ }^{45}$ Interestingly enough, it was members of the governing political coalition who claimed that these electoral results were fraudulent, because thousands of PRN and hundreds of PVP voters were prevented from casting ballots. While fraud directed against the government was unheard of in Costa Rica, the use of fraud and other extra-constitutional devices by all political actors was not.

Until the late nineteenth century, public officials in Costa Rica, as in almost all Latin American countries, were selected in military contests or in fraudulent, often hastily organised elections. ${ }^{46}$ By the turn of the century, access to state offices in Costa Rica began gradually to be determined by intensely competitive and regularly held (albeit frequently fraudulent) electoral contests that did not exclude the threat and/or use of violence. Indeed, between 1889 and the I 948 civil war (during the period

45 Even a casual examination of newspapers during this period reveals the centrality of electoral issues in Costa Rican politics. A Calderonista view of the electoral fraud purportedly exercised against the government can be found in José Albertazzi Avendaño, La Tragedia de Costa Rica, pp. 59-73. An evaluation of this claim, along with the opposition's allegation of fraud, is contained in my 'The Origins of Democracy in Costa Rica in Comparative Perspective', PhD diss., Department of Political Science, Duke University, forthcoming.

46 For analyses of this period, see Cleto González Viquez, El sufragio en Costa Rica ante la bistoria y la legislación (San José, 1975); Rafael Obregón Loría, Conflictos militares y politicos en Costa Rica (San José, I95 I), pp. I-79; and Jorge Saenz Carbonell, El despertar constitucional en Costa Rica (San José, 1985). 
I refer to as the Old Republic), at least four coup attempts and eleven revolts were launched against the central government. ${ }^{47}$

Not only did elements in the government and opposition employ and/or threaten to use violence and fraud to improve their position in electoral jousts, but fractions in each political camp came to the conclusion that only the use of violence would allow them to maintain or capture political power. In late August 1947, for example, certain - reputably Calderonista - elements within the military attempted to assassinate the Minister of Public Security, René Picado (President Picado's brother), to provoke an internal coup against a government that was granting too many concessions to the opposition. ${ }^{48}$ Opposition figures like José Figueres were widely believed to favour the use of military resources to topple what they believed to be a government that would never willingly relinquish power to the opposition. ${ }^{49}$

Despite the existence of hardliners on both sides, numerous attempts were made by most political parties to effect what was often derisively called a transaccion, that is, the selection of a presidential candidate acceptable to both government and opposition. Cortés Castro attempted to negotiate such a compromise with Picado, especially in the aftermath of both the 1944 and the 1946 elections. In fact, he made it publicly clear on at least one occasion that the use of military force to overthrow Calderonismo was not a viable option and thus justified efforts to make a pact with the government. ${ }^{50}$ Throughout 1946, competing parties in the

47 Obregón Loría, ibid., pp. 80-1 16. For more general treatments of this period, see Jorge Mario Salazar Mora, 'El sistema político-electoral Costarricense del período 1914-1948'; Orlando Salazar Mora, Costa Rica: el apogeo de la república liberal, 1870-1914 (San José, 1990) and Mario Samper, 'Fuerzas sociopolíticas y procesos electorales en Costa Rica, I92 I-1938', Revista de Historia (Heredia/San José, Costa Rica) (número especial, 1988).

48 See, for example, 'Fracasó un plan militar para asesinar al Secretario de Seguridad Pública', Diario de Costa Rica, no. 8,5 18 (26 Aug. 1947); 'Cambiará de un momento a otro la situación militar en el cuartel Bella Vista', Diario de Costa Rica, no. 8, 517 (27 Aug. 1947).

49 This was a charge frequently repeated in the pages of the pro-government newspaper, La Tribuna, especially during 1947 and the first months of 1948. Even a summary reading of the PSD's paper, Acción Demócrata, between 1944 and 1947 reveals the adamant unwillingess of Figueres and others in the PSD to consider even compromising with the government. Figueres' own hardline position is revealed in his 'Discurso pronunciado por Don José Figueres (desde Radio Monumental y Titania en la noche del 22 de Agosto de 1946)', La prensa libre, no. 13,892 (24 Aug. 1946), p. 4.

50 In the last interview Cortés granted to a journalist before his unexpected death on 3 March he asked '¿Está el país en disposición de ir a la resistencia armada? Yo no podría lanzar a los partidarios que con tanta abnegación me han seguido, a una asonada que sería una carnicería, porque no considero que esté el pueblo armado en forma que su rebeldía tuviera vislumbres de buen éxito... Por eso he puesto oídos sordos a las insinuaciones de violencia, que sólo podrían merecer el apoyo de los Costarricenses 
opposition tried to negotiate a transaccion with the government that both the PD and PRN were pursuing but each denied was occurring. In the months before the 1948 elections rumours abounded that different members of the government and opposition were conducting negotiations to avoid the armed confrontation that many feared might occur.

From the day that elections were held, numerous attempts were made to mediate the conflict between members of the PRN and the opposition. Within a week of election day, a group of prominent Costa Ricans published an open letter asking Monseñor Sanabria to help them organise an effort to serve as mediators of the emerging political crisis. ${ }^{51}$ Members of the TNE also attempted to effect a compromise, as they came to realise that they would be unable to examine all electoral materials by the constitutionally required 2s March deadline. Three days later, when the TNE, with two members in favour and one abstaining, provisionally declared the election of Ulate Blanco to the presidency, efforts intensified to devise a pact between Calderonistas and the opposition. After the I March session of Congress that annulled the presidential election results, both Monseñor Sanabria and the Association of Bankers worked around the clock to reach a compromise. ${ }^{52}$ But while various formulae were being discussed, word reached San José on I 2 March that José Figueres had attacked government troops sent to discover whether rumours were true that an army was being assembled on his finca.

This brief survey of numerous attempts to reach a compromise makes the point that a peaceful resolution of the conflicts between the government and opposition was possible. Disagreements on the terms of the compromise of the conflict should not obscure the fact that key political actors were willing to sacrifice other goals for the cause of peaceful cooperation. Indeed, by late March, both Calderón Guardia and Ulate Blanco decided that the new Congress, in its first session on I May I948, should select Dr Julio César Ovares as first designate to the

sensatos, cuando llevarán aparejada la preparación adecuada, para que la protesta armada tuviera alguna probabilidad de buen éxito y no significará simplemente un derramamiento inf ructuoso de sangre Costarricense.' Cortés Castro then suggested that a compromise presidential candidate be found for the 1948 elections. 'El último reportaje político de don León Cortés' [entrevista hecha por Sergio Carballo R.], La prensa libre, no. 13,752 (6 March 1946), pp. I, 3.

51 This open letter is dated ro Feb. 1948. It is signed by Luís Davila, José Joaquín Jiménez Núñez, Luís Felipe González Flores, Dr Antonio A. Facio, José Joaquín Alfaro Iglesias, Jorge Guardia, Edmundo Montealgre and J. A. Gutiérrez. See 'El poder ha de ser traspasado al ciudadano que haya obtenido la legítima mayoría electoral del domingo pasado', La prensa libre, no. 14,334 (I Feb. 1948), p. 2.

52 The only existing account to mention these negotiations is Eugenio Rodríguez Vega, De Calderón a Figueres, pp. 179-87. 
presidency. Under this agreement, Dr Ovares would rule as interim president for a period of two years, during which new presidential elections would be held. But when this plan was presented to Figueres for approval, he did not accept its terms. Instead he continued to lead the army that would eventually prove triumphant in the civil war.

The four books I have examined do not discuss these events in any real detail, thus implying that the course taken by events was inevitable. Schifter, for example, in the ten pages of chaper III in La fase oculta de la guerra civil dedicated to exploring the period between 1946 and 1948 , does not even mention any of these efforts to reach a political compromise. Bell does mention some of these efforts in chapters five and six of his book. However, he concludes a bit too hastily that 'the actions of I March closed the way to any alternative other than insurrection'. ${ }^{53}$ Such a conclusion can only be justified if Bell can show that both the government and opposition were unwilling to devise a pact to prevent the outbreak of armed hostilities feared by many. Yet he only hurriedly discusses this period, barely referring to Monseñor Sanabria's efforts and offering no analysis of those made by the Association of Bankers to effect a transaccion. Dr Ovares' transitional candidacy, in fact, is only mentioned in a footnote by Bell. ${ }^{54}$

Similarly Rojas Bolaños only devotes a small number of pages to the analysis of government-opposition relations between 1946 and $1948 .{ }^{55} \mathrm{He}$ also pays little attention to efforts to arrange a compromise between the Calderonistas and the opposition. Even Aguilar Bulgarelli chooses to examine only some of these endeavours, despite spending quite a few pages discussing this period. ${ }^{56}$ For example, he only dedicates one page to Monseñor Sanabria's efforts in the wake of the nullification of the elections by Congress. Neither does Aguilar Bulgarelli make any mention of the Association of Bankers' participation in these and other attempts to reach a peaceful compromise.

The selective coverage of political events apparent in these narratives is well illustrated by Aguilar Bulgarelli's extensive treatment of Calderón Guardia's motives for presenting the Constitutional Congress with a petition requesting that the 1948 presidential elections be annulled. He contends that if Calderón Guardia had really thought the elections were fraudulent, he should have asked Congress to nullify not only the presidential, but also the congressional elections of i 948 . Unfortunately,

53 Bell, Crisis in Costa Rica, pp. $128-9$.

54 See ibid., p. I 35 , n. Io. Bell's minuscule effort to understand the role played by Monseñor Sanabria and the Association of Bankers is to be found on pp. 128-30.

55 See his Lucha social y guerra civil en Costa Rica, 1940-1948, pp. $131-55$.

56 See his Costa Rica y los bechos politicos de 1948, pp. 146-294. The page reference made in the sentence following this footnote is p. 294. 
the plausibility of this argument is undermined by the simple fact that under the Constitution only the new Congress itself, in its first session on I May, was empowered to determine the validity of the election of its new members. ${ }^{57}$

\section{Conclusion: questioning the inevitability thesis}

The tendency not to explore key events and issues in the detail they deserve, along with a set of assumptions privileging the social and/or economic roots of political conflict, have led to the conclusion that the I 948 civil war was inevitable. In combination, these two practices have stifled academic and critical inquiry about the civil war. They alsoperhaps unintentionally - serve to reinforce those interpretations of the civil war explicitly designed to glorify the role played by Figueres in the events of these years. This indeed is a paradoxical result, for Schifter's book is rather anti-Figuerista in tone, Aguilar Bulgarelli's book is often accused of being Calderonista in inspiration, and Rojas Bolaños' volume, at the very least, is not meant to praise the role played by Figueres during the i 940 .

Thus, standard explanations of the origins of the 1948 civil war will remain flawed unless relations between class interests, economic change and political action are specified. Political narratives like those of Aguilar Bulgarelli and Bell do not stand up to scrutiny because they rest upon a questionable understanding of economic and class dynamics as well as a selective analysis of political phenomena. Economic and class perspectives fail to explain why the political conflicts of the r 940 s had to be settled through the force of arms because they employ a set of assumptions that conceive of the political arena as a mere projection of 'real' and inadequately studied conflicts occurring among the material foundations of society. Both approaches lead to the theoretically dubious and empirically unsubstantiated conclusion that the outbreak of violence was inevitable during 1948 in Costa Rica.

57 Marco Tulio Zeledón, Lecciones de ciencia constitucional y la constitución política de la república de Costa Rica (San José, 1945), p. I 20, article 91. The version of the Costa Rican I 871 constitution published in Zeledón's book is updated to include all reforms in effect for the elections of 1948. Aguilar Bulgarelli discusses Calderón Guardia's petition in Costa Rica y sus hechos politicos de 1948 , pp. 267-92. It is worth noting that Aguilar Bulgarelli (ibid., pp. $277-8$, n. 23 ) also errs when he states that the documentary appendices of Calderón Guardia's petition cannot be found, thus preventing analysis of the former president's charges of fraud. While it may be true that the originals are not in the archives either of the Legislative Assembly or of the Supreme Tribunal of Elections, they are available in published form. See La gaceta: diario oficial, no. so (29 Feb. 1948), pp. 366-8; no. 56 (7 March 1948), pp. 409-20. An analysis of these and many other documents will be included in my 'The Origins of Democracy in Costa Rica in Comparative Perspective', forthcoming. 
Contesting the belief that the 1948 civil war was inevitable generates counterfactual speculation, an approach that is deemed less than useful by many. ${ }^{58}$ However, the counterfactuals implied by my reinterpretation of the I940s focus on opportunities missed to negotiate a peaceful compromise to existing political conflicts. They do not serve as inspiration for the construction of hypothetical worlds of what would have happened if certain decisions had not been taken or if alternative choices had been made. Understanding why political actors did not select one or more possible courses of action contributes to explaining why they made the decisions that they actually did. Reconstructing the calculations made by political actors to assess the efficacy of alternative courses of action is perhaps the best way to comprehend how the behaviour of each political actor was constrained by the behaviour of all.

Emphasising the role of political choice in preventing regime breakdown is, in fact, a central feature of important recent work on the collapse and reconstruction of democratic practices. ${ }^{59}$ This approach contends that underlying class conflicts and/or severe economic crises do not compel political actors to undermine democratic practices. This article suggests that analysts of political change need to discern whether institutional arrangements encourage or discourage cooperation, and to explore the opportunities missed or ignored by political actors to resolve their conflicts peacefully.

The 1948 civil war occurred because political parties as well as members and institutions of the state could not reach mutually beneficial compromises regarding the most appropriate way to capture or retain state power. Such inability to mediate differences about political succession within existing institutional arrangements was by no means unusual in

58 Víctor Hugo Acuña warned me of the dangers of counterfactual reasoning. I hope that this paragraph explains that I am not advocating, on this occasion, the development of a 'new political history' like the 'new economic history' (though I might in the future). On the uses of counterfactual reasoning in the social sciences see Jon Elster, Logic and Society: Contradictions and Possible Worlds (New York, 1978); T. A Climo and P. G. A. Howells, 'Possible Worlds in Historical Explanation', History and Theory, 1976; and Peter D. McClelland, Causal Explanation and Model-building in History, Economics and the New Economic History (Ithaca, 1975). Though he uses very different language to make the argument I defend in this paragraph, Miguel Acuna also concurs in the use of counterfactuals to understand the 1948 civil war. See his Calderonista-inspired El 48 , pp. I $5-18,44-5,265,269,375-9$. The book as a whole can be considered as an exploration of a large number of counterfactual propositions about the 1948 civil war.

59 See, for example, Juan J. Linz and Alfred Stepan (eds.), The Breakdown of Democratic Regimes, four volumes (Baltimore, 1978). A particularly good study of a democratic breakdown that also finds inevitabilist theories distasteful is Wanderley Guilherme dos Santos, 'The Calculus of Conflict: Impasse in Brazilian Politics and the Crisis of 1964', unpubl. PhD diss., Stanford University, 1979. Also see Guillermo A. O'Donnell, Philippe Schmitter and Laurence Whitehead (eds.), Transitions from Authoritarian Rule, four volumes (Baltimore, 1986). 
Costa Rica. It was not until the end of the nineteenth century that Costa Rican political actors began to rely on the ballot box to select the occupants of public office. Even when many agreed to compete for state power in the electoral arena, those in control of the executive often used fraud to modify electoral results. Violence was frequently threatened, less often used, but never disavowed as a legitimate political resource by hardline elements in the government, and especially by those in the opposition possessing the loyalty of few voters.

Concentrating on the behaviour of electoral organisations and state officials to explain the outbreak of armed conflict in 1948 does not imply that the behaviour of capitalists is of no political consequence. Indeed, understanding the role of the electoral arena in Costa Rican politics since the end of the nineteenth century requires discerning how public officials pursued policies that placated the interests of coffee exporters, import merchants and bankers. Several decades before the 1948 civil war, for example, Costa Rican capitalists expressed their dislike of the financial and economic policies of President Alfredo González Flores (1914-I7) by supporting a coup organised by ambitious military officers and opposition political parties. ${ }^{60}$

What my re-examination of Costa Rican politics during the i 940 s suggests is that the dominant class appears to have been reluctant to support coup attempts against the central government. The unwillingess of most capitalists to echo the calls of those in the opposition committed to overthrowing, by whatever means necessary, the governments of Calderón Guardia and Picado is understandable, because these governments often pursued policies favouring as well as harming their interests. It is also clear that many capitalists reasoned that armed resistance was not the most useful way to alter public policies they may have found distasteful.

Focusing on the decisions made by political actors also helps to make the paradoxes about the patterns of alliance formation more apparent than real. That the PVP worked with a 'modernising fraction of the national bourgeoisie', and that the 'middle sectors' were in the opposition with 'the most conservative sector of national politics', is only counterintuitive from a perspective that mechanistically links poorly defined class interests to political organisations. All political parties devised strategies to capture state power precisely because different elements in the

60 The standard secondary sources on the overthrow of this president are: Carlos Luís Fallas Monge, Alfredo González Flores (San José, 1976); Eduardo Oconitrillo García, Alfredo González Flores: estadista incomprendido (San José, 1980); Armando Rodríguez, Administración González Flores (San José, 1978); and Bernardo Villalobos Vega, Alfredo González Flores: politicas de seguros y de banca, 1910-1917 (San José, 1981). 
6o Fabrice Edouard Lehoucq

government and opposition had interests that diverged as well as converged. They formed unexpected coalitions with each other because of the choices already made (or in the making) by other political parties. It was the rules in existence regulating access to state office, along with the distribution of political preferences among key groups, that produced the - at first sight - rather strange set of alliances that occurred during the I 940 in Costa Rica. 